\title{
Accumulation and uptake of light rare earth elements in a hyperaccumulator Dicropteris dichotoma
}

\author{
Xiaoquan Shan ${ }^{\mathrm{a}, *}$, Haiou Wang ${ }^{\mathrm{a}}$, Shuzhen Zhang ${ }^{\mathrm{a}}$, Hanfa Zhou ${ }^{\mathrm{b}}$, \\ Yan Zheng ${ }^{\mathrm{c}}$, Hong $\mathrm{Yu}^{\mathrm{a}}$, Bei Wen ${ }^{\mathrm{a}}$ \\ ${ }^{a}$ Research Center for Eco-Environmental Sciences, Chinese Academy of Sciences, P.O. Box 2871, Beijing 100085, China \\ ${ }^{\mathrm{b}}$ Dalian Institute of Chemical Physics, Chinese Academy of Sciences, 457 Zhongshan Road, Dalian 116023, China \\ ${ }^{c}$ School of Earth and Environmental Sciences, Queens College, City University of New York, Flushing, NY 11367, USA
}

Received 22 April 2003; received in revised form 23 July 2003; accepted 30 July 2003

\begin{abstract}
Dicropteris dichotoma, a natural perennial fern, grows in acidic soil in southern China. It hyperaccumulates several light rare earth elements $\mathrm{La}, \mathrm{Ce}$, Pr and Nd (LREEs) up to about $0.7 \%$ of its dry leaf biomass. Through electron microscopic and X-ray microanalyses, LREEs deposits were observed in the cell wall, intercellular space, plasmalemma, vesicles and vacuoles of the root endodermis and stele cells but not in the Casparian band of the fern adventitious root. In addition, LREE deposits were observed in the phloem and xylem of the fern rhizome. These results indicate that at least a portion of the LREEs can be transported symplastically. Histidine and organic acids appear to play a role in stimulating the accumulation of LREEs. This was evident in ferns cultivated in soil amended by histidine, malic and citric acids over a 60 -day period. Concentrations of LREEs in D. dichotoma leaves increased by $21-78 \%$ as opposed to control, which only increased by $6-10 \%$. While this suggests that histidine and organic acids promote the uptake and sequestration of LREEs in $D$. dichotoma, the enhancement mechanism of each acid appears to differ. Histidine promoted sequestration of LREEs by forming complexes with LREEs in cells. Organic acids, however, increased the release of LREE from soil, and the uptake of LREEs by fern roots. Most of the LREEs (81-89\%) in the cell wall are the result of one of these mechanisms involved in LREE hyperaccumulation. Mass analysis indicated that the molecular weight of LREE-binding peptides was approximately 2000 .
\end{abstract}

(C) 2003 Elsevier Ireland Ltd. All rights reserved.

Keywords: Hyperaccumulator Dicropteris dichotoma; Light rare earth elements; LREE-binding peptides

\section{Introduction}

Interest in the phytoremediation of metal-contaminated soils is increasing although this technique is still in its early stage of application [1,2]. Approximate 400 species of metal hyperaccumulators are currently known [3,4]. Of particular physiological interests are those metallophytes that can hyperaccumulate heavy metals such as nickel $(\mathrm{Ni})$, zinc $(\mathrm{Zn})$, copper $(\mathrm{Cu})$, cobalt $(\mathrm{Co})$ and lead $(\mathrm{Pb})$. These are hyperaccumulated from soils enriched with heavy metals either naturally or anthropogenically [5-8].

Considerable progress has been made to illustrate the mechanisms of translocation and sequestration of heavy met-

\footnotetext{
* Corresponding author. Tel.: +86-10-62923560; fax: +86-10-62923563.

E-mail address: xiaoquan@mail.rcees.ac.cn (X. Shan).
}

als in hyperaccumulators. Two transport mechanisms of metals within hyperaccumulators have been identified. These are either through the apoplastic or symplastic pathways. Most studies have identified the apoplastic transport mechanism. This is because the accumulation of $\mathrm{Ni}, \mathrm{Zn}$ and $\mathrm{Cd}$ is found mainly in cell walls, residing on the outside of the plasma membrane of epidermal, cortical and endodermal cells up to the Casparian band [9-16]. At the same time, such accumulation is completely absent from stele [10]. However, movement of ions taken up by plant roots centripetally across the root into the xylem must be symplastic [17]. For example, a significant amount of aluminum is found to accumulate in the symplasm of the root-tip of soybean plants. This would indicate that aluminum can rapidly cross the plasma membrane and is transported symplastically [18].

The understanding of the location of rare earth elements (REEs) in plant cells is still limited and the mechanism 
remains controversial. An electron microscopic study revealed that REEs enter the apoplasm of root meristems and move from there to the stele of the root and to the shoots of intact Hordeum vulgare L., Salicornia virginica L., and Spartina alteniflora Loisel [19]. Lanthanum was only detected in the root cell cytosol when plants were exposed to high concentration of lanthanum for long periods of time. However, this was ascribed to be a toxic response [19]. REEs were also found in the cytoplasmic fraction of plant cells [20]. Here the nucleolus was found to be the site that firmly binds REEs.

Uptake and accumulation of LREEs in plants are influenced by plant root and soil interactions. Hyperaccumulators can solubilize LREEs from soil. This enhances the efficiency of the uptake of LREEs by roots, the translocation of LREEs to leaves, and the sequestration of LREEs within plant shoot cells. Low-molecular-weight organic acids (LMWOAs) are important root exudates. This is due to their metal chelating and/or complexing properties by which they can influence metal solubility in soils and uptake by plants [21-24]. Although organic acids participate in the metal complex in the shoots of hyperaccumulators, they are already normally present at high concentration levels in most terrestrial plants and therefore would not account for metal specificity resulting from hyperaccumulation. Of all the organic acids and proteinaceous amino acids, histidine has the highest association constant for complex formation with heavy metals at typical cytosolic $\mathrm{pH}$ values around 7.5 [3].

Dicropteris dichotoma is a natural perennial fern that hyperaccumulates LREEs. The tolerance to elevated LREEs in soils and high accumulation of LREEs in the leaves were previously reported [25]. Guo et al. [26] isolated REE-binding proteins with molecular weights of 14,100 and 38,700. Wang et al. [20,27] reported that REEs bound with DNA and with polysaccharides in the leaves of $D$. dichotoma. Lanthanides might replace magnesium of chlorophyll partly and form new metal-chlorophyll complexes. The complexes would be in sandwich-like form based on K-absorption near-edge spectra of $\mathrm{Ce}$ in $D$. dichotoma by extended X-ray absorption fine structure spectroscopy [28]. However, the biochemical mechanisms involved remain obscure.

Physiologically, trivalent cations, such as $\mathrm{La}^{3+}$, are notoriously difficult to study because of their aggressive binding to negatively charged ligands in the plant cell wall. There has been very little convincing data on the translocation of REEs and specifically on the effects of organic acids on the uptake and accumulation of REEs by a hyperaccumulator such as $D$. dichotoma. Therefore, the main goals of the present investigation include: (1) the study of the subcellular location and transport mechanism of LREEs in the fern; (2) the assessment of whether histidine and organic acids have positive, negative or neutral effects on the hyperaccumulation of LREEs by the fern; (3) the observation of LREEs distribution among cell walls, cell debris, peptides, free amino acids, and pigments of the fern leaves.

\section{Materials and methods}

\subsection{Plant material}

In December 2001, the natural perennial fern, $D$. dichotoma, was sampled together with its native soil. This was done in area where there is rare earth ore deposit in southern China. The fern and the soil were then transferred to 21 culture pots and cultured in the laboratory for further electron microscopic study and X-ray microanalysis (see Section 2.2), and for the amendments of histidine and organic acids (see Section 2.4).

Additional samples of fresh fern leaves were obtained in the field and stored frozen for isolation of cellular components. The fresh fern leaves were cut off on site, cleaned with deionized water, blotted with paper tissues, and then placed in an envelope. The envelopes containing fern leaves were immediately frozen in liquid nitrogen and were kept frozen during transport. The samples were stored in a refrigerator at $-80^{\circ} \mathrm{C}$ until isolation of cellular components took place (see Sections 2.3 and 2.5).

\subsection{Electron microscopic study and X-ray elemental microanalysis}

For electron microscopic analysis, an intact fern was thoroughly rinsed with tap water and distilled water, and then blotted with paper tissues. The tip root and rhizome were excised. The plant samples $\left(1 \mathrm{~mm}^{3}\right)$ were fixed in $3 \%(\mathrm{w} / \mathrm{v})$ glutaraldehyde and in a $0.1 \mathrm{M}$ phosphate buffer ( $\mathrm{pH}$ 7.2) for $4 \mathrm{~h}$, and washed with a phosphate buffer for $1 \mathrm{~h}$. Then, the samples were fixed with $1 \% \mathrm{OsO}_{4}(\mathrm{pH} 7.2)$ for $1 \mathrm{~h}$, and rinsed with a buffer for three $10 \mathrm{~min}$ periods. After washing, the samples were dehydrated in a graded acetone and ethanol in series, and then embedded in Spurr's resin for 3 days. Dry sections $(1-2 \mu \mathrm{m})$ were cut on a diamond knife using an ultramicrotome and mounted on copper grids. Electron microscopic observation was made at $100 \mathrm{kV}$ with a Hitachi 800 electron microscope. Elemental X-ray microanalysis was performed using a Philips EDAX 9100 microscope. A scanning transmission electron micrograph was first taken at $100 \mathrm{kV}$, followed by microanalysis for $100 \mathrm{~s}$ of $5.0 \mathrm{~nm}$ spots.

\subsection{Determination of free histidine and organic acids in the fern leaves}

Fresh leaf tissues $(5.0 \mathrm{~g})$ were ground to very fine powder with a pestle in a mortar kept chilled on an ice-bath. Precautions were taken to keep the tissue frozen throughout the grinding process with the help of additional liquid nitrogen. The tissue powder was suspended in $10 \mathrm{ml}$ deionized water before centrifugation in a Beckman JA 14 rotor at $10,000 \times g$ for $10 \mathrm{~min}$. The supernatant was filtered through a $0.45 \mu \mathrm{m}$ filter membrane. The filtrate was used for 
determinations of histidine and organic acids by ion chromatography and capillary zone electrophoresis (CZE), respectively.

The determination of histidine was accomplished using a DX-600 ion chromatograph (Dionex, Sunnyvale, CA, USA). The AminoPac PA 10 column set consisting of a guard column $(50 \mathrm{~mm} \times 2 \mathrm{~mm}$ i.d. $)$ and an analytical column $(250 \mathrm{~mm} \times 2 \mathrm{~mm}$ i.d. $)$ were used to separate amino acids and carbohydrates. The specific details of this were reported elsewhere [29].

All CZE experiments were performed using a Beckman P/ACE System 2050 capillary electrophoresis system controlled by a computer equipped with Gold software. Separation was carried out in fused-silica capillaries $(50 \mu \mathrm{m}$ i.d. $\times$ $75 \mathrm{~cm}$ total length, $70.4 \mathrm{~cm}$ effective length) at a voltage of $20 \mathrm{kV}$ with the cathode on the detector side. The capillary was kept at a constant temperature of $25^{\circ} \mathrm{C}$ by a thermostat. Sample injection was accomplished by voltage $(5 \mathrm{~s})$ or mainly by pressure injection at $0.5 \mathrm{psi}$ for $5 \mathrm{~s}$. The signal was measured by the indirect UV detection mode at $254 \mathrm{~nm}$.

\subsection{Histidine and organic acid amendments}

Eight culture pots containing the fern with the original adjacent acidic soils were used to investigate the effects of histidine and organic acid amendments on LREEs uptake. Two pots each were used for control and for amendments. An amendment with $100 \mathrm{ml}$ of $0.01 \mathrm{M}$ histidine, $0.01 \mathrm{M}$ citric acid, and $0.01 \mathrm{M}$ malic acid was added daily for 60 days, respectively. The growth temperature during cultivation was about $15^{\circ} \mathrm{C}$ at night and about $25^{\circ} \mathrm{C}$ during the day. After 60 days, the fern leaves were harvested from each pot for determination of LREE concentrations (see Section 2.7).

\subsection{Isolation of cellular components}

Only the frozen fern leaves (see Section 2.1) were used for the isolation of cell wall, cell debris and peptides following a protocol of Sugaya et al. [30] with modification (Fig. 1). Briefly, $20 \mathrm{~g}$ of frozen leaves were ground for at least 30 min with a pestle in a large mortar, which was kept chilled by an ice-bath. Liquid nitrogen was also added throughout the grinding process to keep the tissue frozen. After the tissue was ground to a very fine powder, it was suspended in a 10 volume $(\mathrm{w} / \mathrm{v})$ peptide extraction buffer (0.2 M Tris- $\mathrm{HCl}$, pH 8.0) containing $1 \mathrm{mM}$ EDTA, $20 \mathrm{mM}$ 2-mercaptoethanol, $1 \mathrm{mM}$ phenylmethylsulfonyfluoride (PMSF) and sodium dodecyl-sulphonate (SDS). The mixture was homogenized with a Polytron. The homogenate was filtered through four-layer cheesecloth to remove the residue. The filtrate was centrifuged in Beckman JA 14 rotor at $20,000 \times g$ for 20 min to yield the crude extract and to remove cell debris. The resulting supernatant (crude extract) was precipitated with $30-85 \%$ ammonium sulfate by stirring for $120 \mathrm{~min}$ at $4{ }^{\circ} \mathrm{C}$ under nitrogen atmosphere inside a glove box. The suspension was centrifuged at $6000 \times g$ for $10 \mathrm{~min}$ in a JA 14 rotor. The precipitated fraction was re-suspended in $20 \mathrm{ml} 0.05 \mathrm{M}$ Tris- $\mathrm{HCl}(\mathrm{pH}$ 8.0), after which the mixture was stirred for $45 \mathrm{~min}$ at $4{ }^{\circ} \mathrm{C}$. After centrifugation at $10000 \times g$ for $10 \mathrm{~min}$, the newly resulting supernatant was saved, which was designated as crude LREE-binding peptides.

The crude LREE-binding peptides obtained were loaded on a Sephadex G-25 column $(1.8 \mathrm{~cm}$ i.d. $\times 30 \mathrm{~cm})$ equilibrated with $0.05 \mathrm{mM}$ Tris- $\mathrm{HCl}$ buffer ( $\mathrm{pH}$ 8.0). Then, the column was washed with the same buffer at a flow rate of $1 \mathrm{ml} \mathrm{min}^{-1}$ until the eluate was peptide-free by determination of absorbance at $280 \mathrm{~nm}$. The first peak was collected at every 5-ml fraction. All fractions were combined together

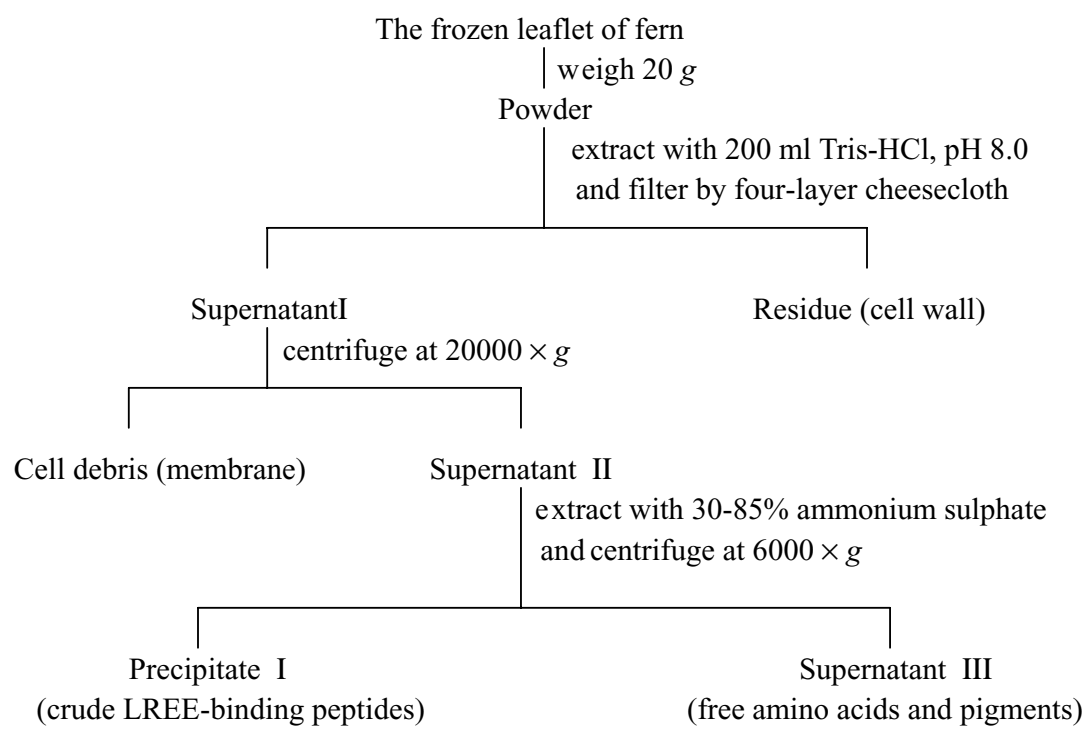

Fig. 1. A schematic diagram of isolation of fern leaf into cell wall, cell debris, crude proteins and peptides, free amino acids and pigments. 
and then concentrated to about $5 \mathrm{ml}$ for HPLC-ESI-MS analysis.

\subsection{Characterization of LREE-binding peptides by HPLC-ESI-MS}

Separation of LREE-binding peptides was performed on an Agilent 1100 series HPLC (Palo Alto, CA, USA) equipped with an autosampler. All connections were made with $0.127 \mathrm{~mm}$ i.d. polyether ether ketone (PEEK) tubing and finger tight fittings (Up-church Scientific). Chromatographic analysis was performed with a reversed-phase $\mathrm{Vy}$ dac $\mathrm{C}_{18}$ column $(150 \mathrm{~mm} \times 4.6 \mathrm{~mm}$ i.d.; particle size $5 \mu \mathrm{m}$; pore size $300 \AA$ ). A flow-rate of $0.5 \mathrm{ml} \mathrm{min}^{-1}$ was used for all samples in HPLC-ESI-MS analysis. Elution was carried out with a gradient from 0 to $90 \% \mathrm{~B}$ during a $30 \mathrm{~min}$ period. Gradient elution was performed with solvent A $(0.05 \%$, v/v, aqueous TFA) and solvent B (0.05\%, v/v, TFA in acetonitrile). An injection of $20 \mu \mathrm{l}$ samples was used according to ref. [31] and the UV absorption of peptide fraction was measured at $280 \mathrm{~nm}$.

The HPLC effluent was analyzed with an Agilent ESI-mass spectrometer. Agilent ChemSation software controlled HPLC and mass spectrometer.

A post-column addition of glacial acetic acid was delivered at a flow rate of $100 \mu \mathrm{min}^{-1}$ in order to negate the signal suppressing properties of TFA in the mobile phase. The glacial acetic acid was added to the column effluent by using a PEEK "Y" connector (Up-church) and a syringe pump (Cole Parmer). The "Y" was connected to the electrospray interface with $30 \mathrm{~cm}$ of PEEK tubing. The length of the "Y" tubing and point of entry in the ESI source were crucial for adequate mixing of the acid with the column effluent.

A variable fragmentation voltage was used during the ESI detection. The optimized voltage ramp was found to be $\mathrm{m} / \mathrm{z}$ $500=60 \mathrm{~V}, m / z 1000=120 \mathrm{~V}$, and $m / z 3000=220 \mathrm{~V}$. In addition, the following parameters were used for MS detection of the chromatographic eluent: gain, 5; step size, 0.15; drying gas, $101 \mathrm{~min}^{-1}$; drying gas temperature, $350^{\circ} \mathrm{C}$; nebulizer pressure, $25 \mathrm{psi}(1 \mathrm{psi}=6894.76 \mathrm{~Pa})$; capillary voltage, $4500 \mathrm{~V}$.

\subsection{Determination of LREEs}

Before a determination of the concentration of LREEs was made, soil and fern tissue samples were subjected to pre-treatment procedures. Soil samples were air-dried, ground and passed through a 2-mm screen to remove rocks, roots, and other large particles. Before analysis, precautions were taken to avoid contamination during sampling, drying, and grinding. The root, leaf and ground stem (rhizome) of the fern were washed with tap water and with deionized water successively. They were then blotted with paper tissues. The cleaned fern tissue was cut into small pieces with stainless steel knife and dried at $80^{\circ} \mathrm{C}$ for $48 \mathrm{~h}$. It was then ground utilizing an agate mortar and pestle until it could pass through a $0.85-\mathrm{mm}$ (20 mesh) sieve.

A portion $(0.100 \mathrm{~g})$ of air-dried soil or dried fern tissue was decomposed with a mixture of $3 \mathrm{ml} \mathrm{HNO}_{3}+1 \mathrm{ml}$ $\mathrm{HClO}_{4}+1 \mathrm{ml} \mathrm{HF}$ under high-pressure conditions. This has been detailed previously [32]. A portion $(2 \mathrm{ml})$ of the peptide, fractionated by Gel filtration, was accurately taken into a Teflon vessel. It was then decomposed with mixture of $3 \mathrm{ml} \mathrm{HNO}_{3}+1 \mathrm{ml} \mathrm{HClO}_{4}$. The determination of LREEs in soil and plant samples was accomplished by inductively coupled plasma mass spectrometry (ICP-MS) (Plasma Quad III, UK) [33]. During the determination, a solution $\left({ }^{115} \mathrm{In}\right.$ at a concentration level of $10 \mathrm{ng} \mathrm{ml}^{-1}$ in $2 \% \mathrm{HNO}_{3}$ ) was also used as an internal standard to compensate for matrix suppression and signal drifting.

\section{Results and discussion}

\subsection{Distribution of LREEs among soil, root and different components of $D$. dichotoma leaves}

The concentration of LREEs was determined in the soil, as well as the adventitious root, rhizome and leaf of the fern collected from the field. The concentration of LREEs in fern dry leaves was approximately $0.7 \%$. The ratios of the concentrations of $\mathrm{La}, \mathrm{Ce}, \mathrm{Pr}$ and $\mathrm{Nd}$ in leaves to those in roots were $12-15,25-26,3-12$ and $1-7$, respectively (Table 1 ). However, no hyperaccumulation phenomenon was observed for the medium and heavy REEs (data not shown).

Fig. 1 depicts a schematic program for the isolation of the frozen fern leaves to cell wall, cell membrane debris, crude peptides, free amino acids and pigments. The total concentration of LREEs in leaves and the distribution of LREEs among individual component are shown in Table 2. Most of the LREEs (81-88\%) were found in the cell wall portion of the leaf (Table 2). This is consistent with previous studies [33,34]. Cell membrane debris contained about $10 \%$ of the total LREEs. The percentages of the LREEs found in the free amino acids and pigments and in crude peptides were about $0.4-1 \%$ and about $1-3 \%$, respectively (Table 2).

These observations support the notion that the high accumulation of LREEs in cell wall is responsible for the tolerance of LREE hyperaccumulation in $D$. dichotoma. The most likely explanation is that there are many carboxylate groups in cell wall, and those radicals can bind with LREE ions effectively [35].

\subsection{Electron microscopic study and energy-dispersive $X$-ray microanalysis}

Scanning electron microscopic and energy-dispersive $\mathrm{X}$-ray microelemental analyses revealed no LREEs deposits in the Casparian band of the fern adventitious root (Fig. 2a). Instead, the deposition of LREEs was confirmed 
Table 1

Concentrations of rare earth elements in the fern leaves, roots and soil ( $n=5, \mu \mathrm{gg}^{-1}$, dry mass)

\begin{tabular}{lcccc}
\hline & La & Ce & Pr & Nd \\
\hline Leaf & $1503.4-2148.4$ & $2829.7-3956.6$ & $463.5-609.5$ & $1023.1-1358.7$ \\
Rhizome & $213.3-544.4$ & $233.7-243.0$ & $105.1-126.3$ & $337.8-352.4$ \\
Adventitious root & $118.8-141.5$ & $108.4-157.7$ & $36.9-201.5$ & $146.3-1247.9$ \\
Soil & $150.5-453.1$ & $244.9-281.1$ & $33.1-137.1$ & $119.2-474.9$ \\
\hline
\end{tabular}

Table 2

Concentrations of rare earth elements in different components of fern leaves $\left(n=5, \mu \mathrm{gg}^{-1}\right.$, dry mass)

\begin{tabular}{|c|c|c|c|c|c|c|c|c|}
\hline & \multicolumn{2}{|l|}{$\mathrm{La}$} & \multicolumn{2}{|l|}{$\mathrm{Ce}$} & \multicolumn{2}{|l|}{$\operatorname{Pr}$} & \multicolumn{2}{|l|}{$\mathrm{Nd}$} \\
\hline & $\mu \mathrm{gg}^{-1}$ & $\%$ & $\mu \mathrm{gg}^{-1}$ & $\%$ & $\mu g^{-1}$ & $\%$ & $\mu \mathrm{gg}^{-1}$ & $\%$ \\
\hline Crude peptides & $20.8 \pm 1.3$ & 1.0 & $102.4 \pm 13.6$ & 2.7 & $7.0 \pm 0.6$ & 1.2 & $17.9 \pm 4.7$ & 1.4 \\
\hline Free amino acids and pigments & $11.3 \pm 0.8$ & 0.5 & $36.8 \pm 3.8$ & 1.0 & $2.6 \pm 0.1$ & 0.4 & $6.4 \pm 0.2$ & 0.5 \\
\hline Cell debris (membrane) & $212.6 \pm 15.1$ & 10.4 & $577.9 \pm 45.8$ & 15.4 & $57.1 \pm 10.3$ & 9.6 & $125.9 \pm 12.9$ & 10.1 \\
\hline Cell wall & $1802.6 \pm 87.3$ & 88.1 & $3031.6 \pm 265.4$ & 80.9 & $527.6 \pm 23.1$ & 88.8 & $1094.1 \pm 53.7$ & 87.9 \\
\hline Leaflet & $2047.3 \pm 165.3$ & 100.0 & $3748.3 \pm 312.5$ & 100.0 & $594.5 \pm 45.7$ & 100.0 & $1244.9 \pm 86.5$ & 100.0 \\
\hline
\end{tabular}

in the plasmalemma, vesicle and vacuole of the endodermis cells of the adventitious root of the fern (Fig. 2a). These results demonstrated that the LREE permeated the Casparian band. This significantly differed from other studies, which considered Casparian band as a barrier to the movement of lanthanum from cortex to stele [36].

LREE deposits were also observed in the cell wall, plasmalemma, vesicle, vacuole and intercellular space of root stellar cell (Fig. 2c), rhizome phloem (Fig. 2d) and rhizome xylem (Fig. 2e). These suggest that at least a partial cell-to-cell transport mechanism is taking place. These results indicate that both symplastic and apoplastic transport mechanisms co-exist in this natural perennial fern.

\subsection{Effect of free histidine and organic acids on uptake of LREES}

D. dichotoma cultivated in soil amended with organic acids or histidine (see Section 2.4) was used to examine the assumption that organic ligands can stimulate the uptake or translocation of heavy metals in hyperaccumulators. Specifically, the intent was to evaluate whether uptake and translocation of LREEs were stimulated by histidine and organic acids.

\subsubsection{Hyperaccumulation of LREEs enhanced by histidine complexation in cells}

After the fern soil was amended for 60 days by L-histidine, the concentrations of LREEs in leaves increased by $21-34 \%$, while those in control leaves only increased by $6-10 \%$ (Table 3). This modest increase of LREEs in fern leaves amended with histidine suggests that free histidine was involved in the uptake and translocation of LREEs from root to leaves and the sequestration of LREEs in fern leaves. This apparent importance of histidine in LREE hyperaccumulation in D. dichotoma is in agreement with their role in nickel uptake by $A$. lesbiacum $[3,4,10,12]$, as well as zinc uptake by Thlaspi caerulescens [3,12].

High concentrations of histidine in leaf cells also indicate that histidine could facilitate plant cell loading of LREEs. This may be possible because the LREE complex can easily form in the presence of histidine $[3,12]$. Through ion chromatography (see Section 2.4), histidine was identified as the most enriched component of the fern sap (Fig. 3). The concentration of free histidine in the leaf cell sap was estimated to be about $128 \mathrm{mM}$. Several other amino acids such as arginine, threonine, serine and leucine were detected in the fern leaves but at lower concentrations (Fig. 3). Histidine can readily complex with LREEs due to high stability constants between LREEs and histidine (Table 4) [37,38] and the high protonation constant of histidine [39]. At the $\mathrm{pH}$ values commonly found in the cytoplasm ( $\mathrm{pH} 7.5)$, histidine is an ideal ligand for LREEs.

\subsubsection{Hyperaccumulation of LREEs by malic and citric acids promoted desorption from soil and enhanced uptake by $D$. dichotoma}

Malic and citric acids were separated from the fresh fern leaves and determined by capillary zone electrophoresis (see Section 2.4). The determination of citric acid was hindered because of matrix interference, and only malic acid was de-

Table 3

Effects of free histidine, malic and citric acids on accumulation of LREEs in D. dichotoma ( $n=2, \mu \mathrm{gg}^{-1}$, dry fern leaf mass)

\begin{tabular}{|c|c|c|c|c|c|c|c|c|}
\hline & \multicolumn{2}{|l|}{ Control } & \multicolumn{2}{|c|}{ Histidine } & \multicolumn{2}{|c|}{ Malic acid } & \multicolumn{2}{|c|}{ Citric acid } \\
\hline & Before & After & Before & After & Before & After & Before & After \\
\hline $\mathrm{La}$ & 63.4 & 67.6 & 72.4 & 95.5 & 136.0 & 163.9 & 62.8 & 111.9 \\
\hline $\mathrm{Ce}$ & 223.0 & 239.6 & 222.2 & 299.2 & 460.1 & 541.6 & 236.4 & 430.2 \\
\hline $\operatorname{Pr}$ & 7.0 & 7.7 & 8.4 & 10.7 & 16.3 & 20.1 & 9.7 & 16.5 \\
\hline $\mathrm{Nd}$ & 15.5 & 17.1 & 16.4 & 20.0 & 33.1 & 38.0 & 21.1 & 31.0 \\
\hline
\end{tabular}


(a)

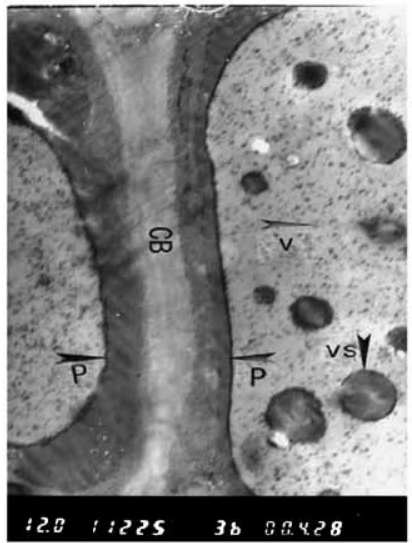

(b)
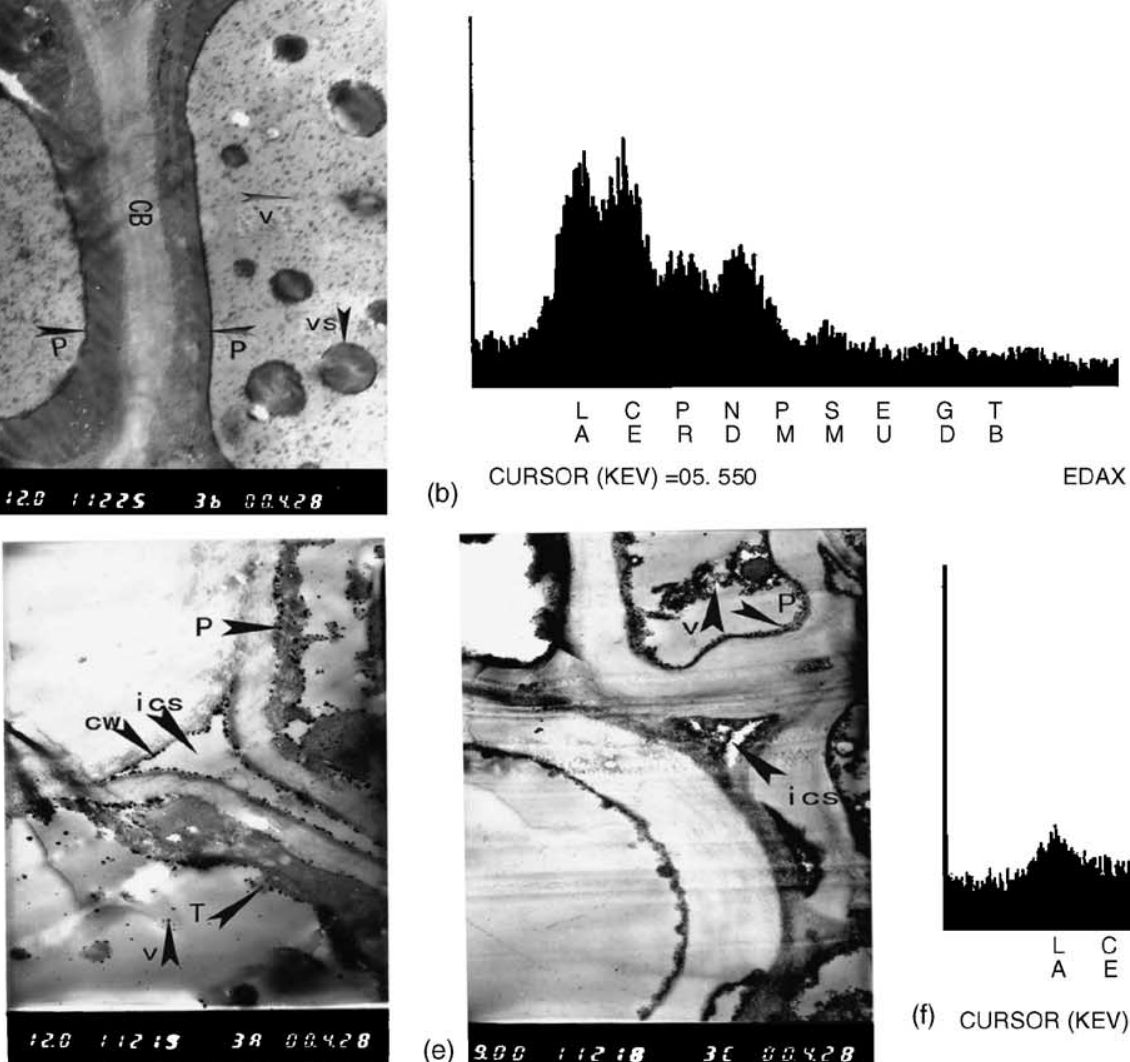

CURSOR (KEV) $=05.550$

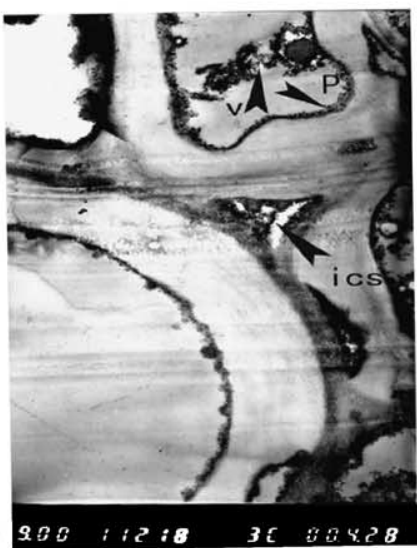

(e) 205 i: $2: 8$ 3E 32428

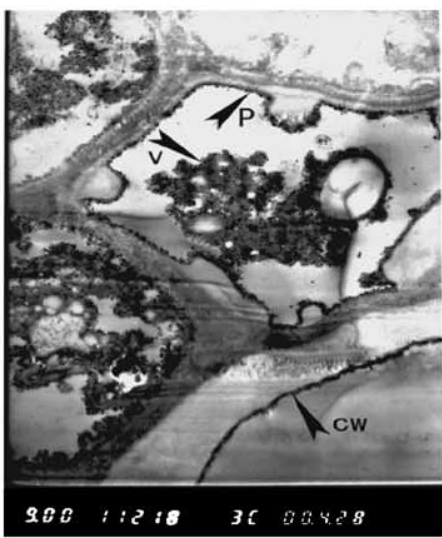

(c)

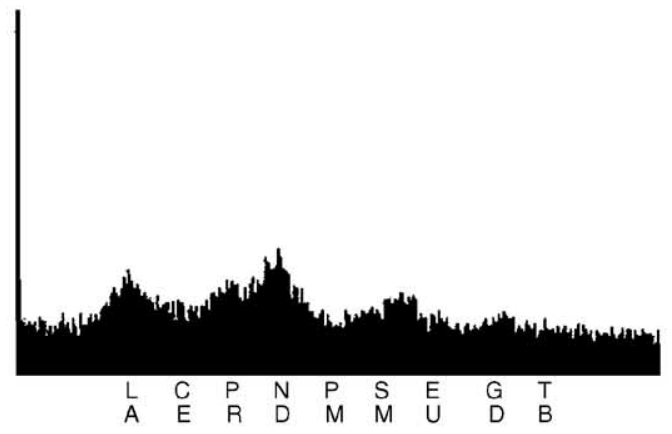

(f) CURSOR (KEV) $=05.530$
EDAX

Fig. 2. Scanning transmission electron micrographs of fern adventitious root (a), root stellar cell (c), rhizome phloem (d), rhizome xylem (e), and X-ray microelemental analysis of adventitious root (b) and rhizome xylem (f). A $5.0 \mathrm{~nm}$ spot of plasmalemma of endodermis cell (a) and rhizome xylem (e) were used for the X-ray microelemental analysis of accompanying scanning transmission electron micrographs. Arrows refer to the deposit of rare earth elements. CB: Casparian band, cw: cell wall, ics: intercellular space, P: plasmalemma, T: tonoplast, v: vacuole, vs: vesicle. Expansion scale of (a), (c), (d) and (e) is 12,000, 9000, 12,000 and 9000, respectively.

tected. The electrophoretogram is shown in Fig. 4. The concentration of malic acid detected was $0.65 \mathrm{mM}$. In addition, a quantitative recovery of $109 \%$ was obtained when standard malic acid was added before grinding the leaf.

By supplying malic and citric acids to fern soils for 60 days, the concentrations of LREEs in fern leaves increased by $21-28 \%$ and by $48-78 \%$, respectively (Table 3 ). The enhanced uptake in the presence of citric or malic acids is most likely caused by the increase in LREEs being release from soil, thus making LREEs easily available to plants [40]. The desorption of LREEs from soil by organic acids, in which the natural perennial fern was grown, followed the order: citric acid $>$ malic acid. This order is consistent with the stability constants of complexes formed between LREEs and organic acids (Table 4) in which citric acid displayed the highest value. This order also suggests that the formation

Table 4

$\mathrm{p} K_{\mathrm{a}}$ values of organic acids and stability constants of LREE-ligand complexes

\begin{tabular}{|c|c|c|c|c|c|}
\hline \multirow[t]{2}{*}{ Organic acid } & \multirow[t]{2}{*}{$\mathrm{p} K_{\mathrm{a}}$} & \multicolumn{4}{|l|}{ Stability constants } \\
\hline & & $\mathrm{La}^{3+}$ & $\mathrm{Ce}^{3+}$ & $\operatorname{Pr}^{3+}$ & $\mathrm{Nd}^{3+}$ \\
\hline Citric acid & $3.13,4.78,6.43$ & $7.17 \pm 0.08^{\mathrm{a}}, 3.00 \pm 0.20^{\mathrm{a}}$ & $7.40 \pm 0.08^{\mathrm{a}}, 3.00 \pm 0.20^{\mathrm{a}}$ & $7.95 \pm 0.04^{\mathrm{b}}$ & $7.96 \pm 0.08^{\mathrm{b}}$ \\
\hline Malic acid & $3.46,5.10$ & $4.37 \pm 0.01^{\mathrm{a}}, 2.79 \pm 0.03^{\mathrm{a}}$ & & $4.65 \pm 0.01^{\mathrm{a}}, 3.09 \pm 0.03^{\mathrm{a}}$ & $4.77 \pm 0.01^{\mathrm{a}}, 3.17 \pm 0.02^{\mathrm{a}}$ \\
\hline Histidine & $\begin{array}{l}2.16,5.36 \\
6.70,7.92\end{array}$ & $4.10 \pm 0.12^{\mathrm{c}}$ & $4.6 \pm 0.2^{\mathrm{d}}$ & $4.36 \pm 0.03^{\mathrm{c}}$ & $4.40 \pm 0.09^{c}$ \\
\hline
\end{tabular}

$\mathrm{p} K_{\mathrm{a}}$ values were adopted from ref. [37]. Stability constants were adopted from ref. [38].

${ }^{\mathrm{a}}$ Ionic strength $I=0.1,25^{\circ} \mathrm{C}$.

${ }^{\mathrm{b}}$ Ionic strength $I=0.05,25^{\circ} \mathrm{C}$.

c Ionic strength $I=3,25^{\circ} \mathrm{C}$.

${ }^{\mathrm{d}}$ Ionic strength $I=0.1,20^{\circ} \mathrm{C}$. 


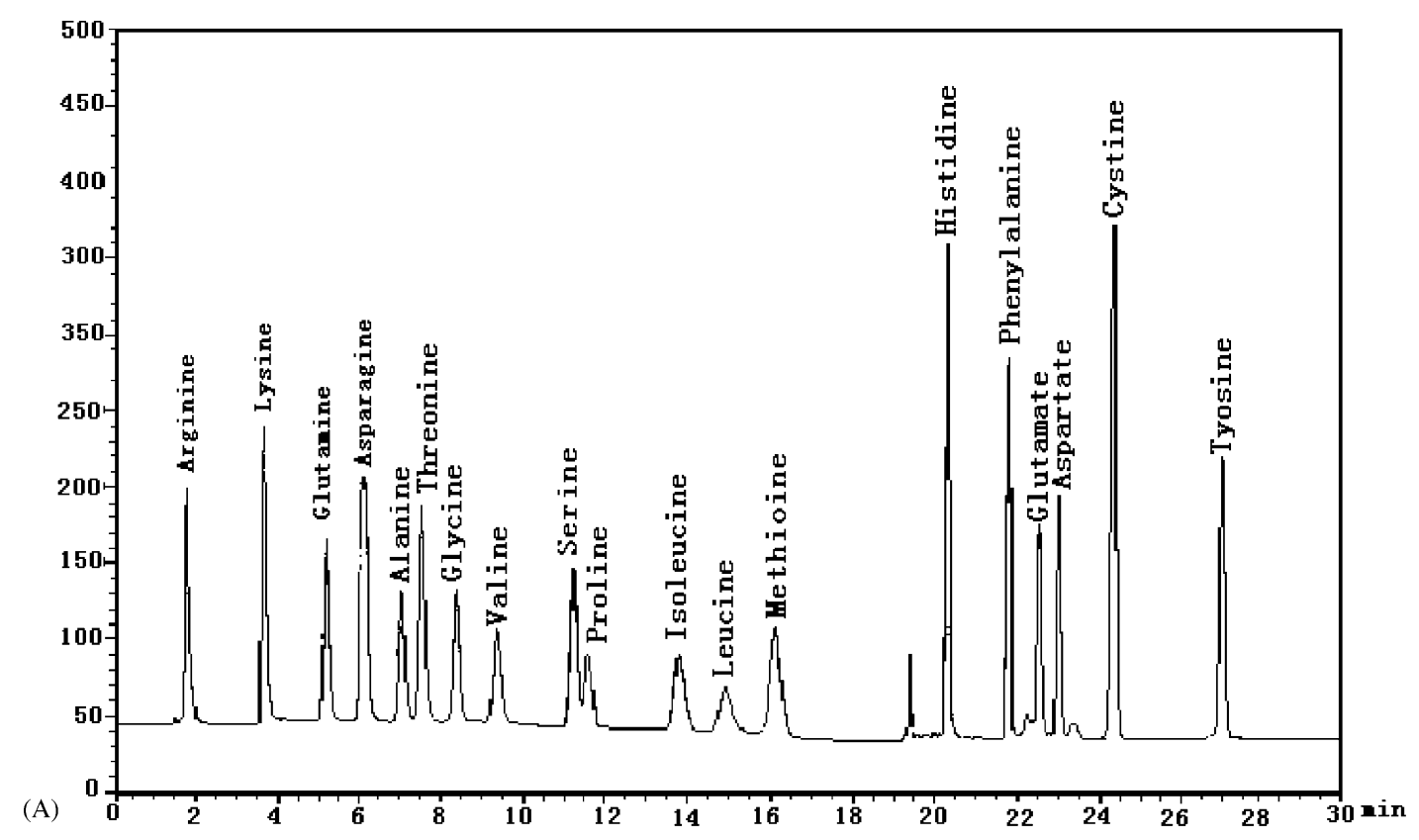

(B)

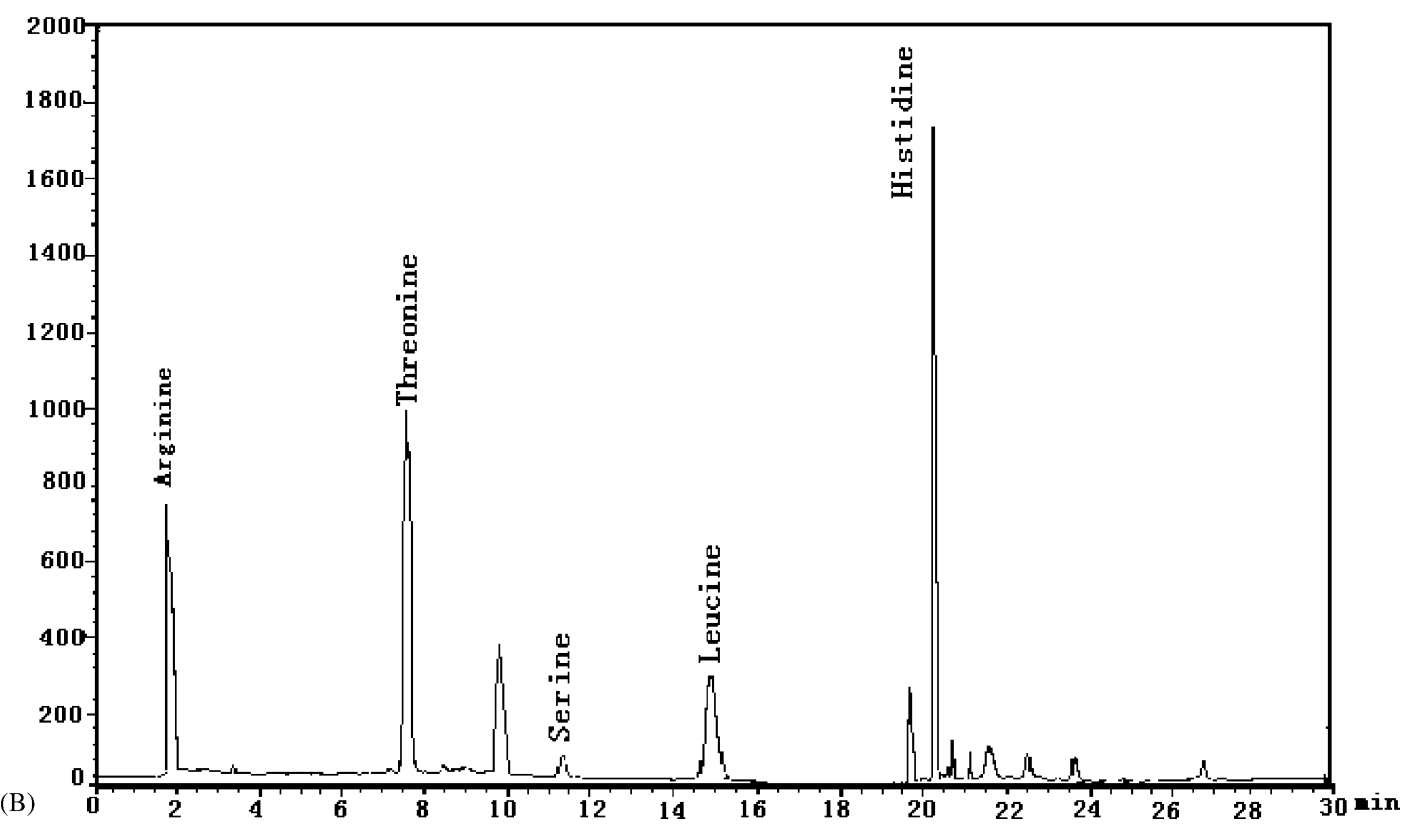

Fig. 3. Chromatogram of histidine by ion chromatography: (A) standard amino acids and (B) amino acids in fern cell sap.

of aqueous LREE-organic ligand complexes is one of the important reasons for the uptake of LREEs by this fern hyperaccumulator.

Enhancement of LREEs uptake by fern amended by organic acids is also supported by a previous study [32]. In that study, a good correlation (correlation coefficient 0.7253-0.9635) was found between concentrations of LREEs by malic and citric acids extraction from soil and those of plants. The results suggested that malic-citric acid extracted LREEs were bioavailable for plants. In a hydroponic culture study, organic acids enhanced the uptake of lanthanum although a different plant species was used [41].

In addition to ligand-promoted desorption of LREEs from soil, citric and malic acids may also enhance LREEs uptake by shuttling metal from root to shoot. High concentrations of malic acid were found in the shoot tissues of T. caerulescens $[42,43]$. This suggests that organic acids such as malic and citric acids may play a key role in the cells. It is also likely that organic ligands help to facilitate the long-distance transport of LREEs in the xylem and might be instrumental in sequestering LREEs in the leaf 


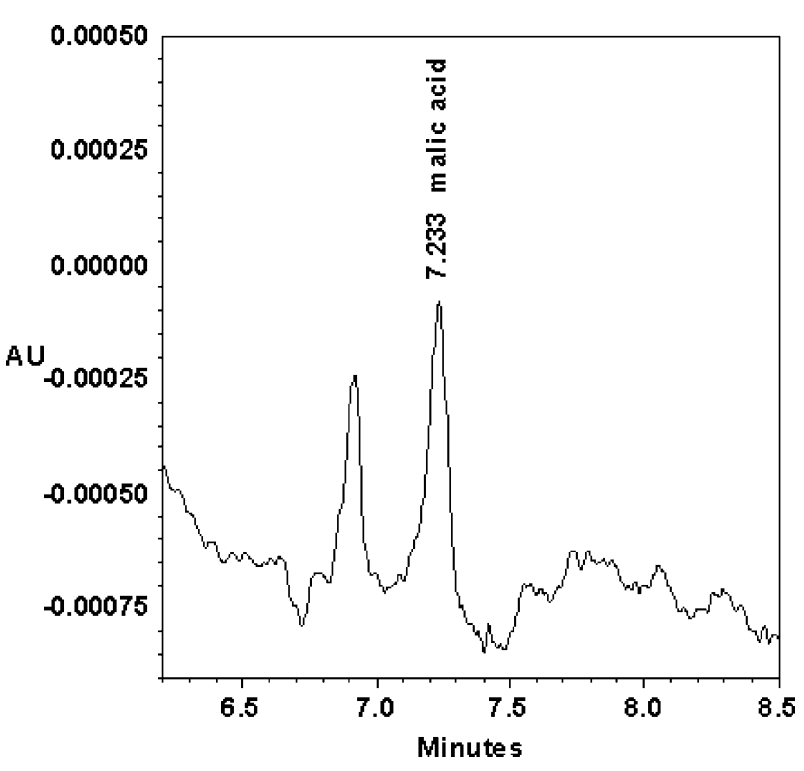

Fig. 4. Electrophoretogram of malic acid in fern leaf cell sap.

cell wall. Both citritrate and malate are intermediates in glycometabolism and are involved in the energy production in the tricarboxylic (TCA) cycle. Citric and malic acids are also strong ligands for LREEs [38]. Therefore, it is conceivable that citric and malic acids can take part in glucose synthesis metabolism, resulting in LREEs being deposited on the cell wall. Further study of the complexation between citric and malic acids and LREEs in hyperaccumulators is required to test this hypothesis.

In summary, although the mechanisms of enhancement differ, both histidine and organic acids (e.g. citric and malic
Table 5

Concentrations of rare earth elements in HPLC eluates with different retention times ( $n=5, \mathrm{ng} \mathrm{g}^{-1}$, fresh leaf mass)

\begin{tabular}{lllll}
\hline Retention time (min) & La & $\mathrm{Ce}$ & $\mathrm{Nd}$ & $\mathrm{Pr}$ \\
\hline 8.325 & 0.62 & 1.42 & 0.54 & 0.14 \\
9.118 & 0.48 & 2.06 & 0.26 & 0.09 \\
9.491 & 0.55 & 1.23 & 0.33 & 0.11 \\
9.965 & 0.42 & 1.37 & 0.32 & 0.09 \\
10.611 & 0.47 & 1.09 & 0.29 & 0.09 \\
12.265 & 0.66 & 1.94 & 0.45 & 0.12 \\
12.832 & 0.69 & 1.34 & 0.25 & 0.10 \\
13.371 & 0.98 & 3.10 & 0.54 & 0.18 \\
13.978 & 1.43 & 4.31 & 0.86 & 0.26 \\
17.551 & 0.55 & 1.21 & 0.42 & 0.08 \\
\hline
\end{tabular}

acids) stimulate the uptake of LREEs in soil by hyperaccumulator $D$. dichotoma and sequestration of LREEs in fern leaves. Histidine promoted sequestration of LREEs by forming complexes with LREEs in cells. Organic acids increased LREE desorption from soil, and also enhanced the uptake of LREEs in the soil solution by fern roots.

\subsection{Characterization of LREE binding peptides}

Hyperaccumulators such as D. dichotoma often utilize several defense strategies against metal stress. Several mechanisms for such a defense include: compartmentation of metals in vacuoles $[33,44,45]$, complexing of metal ions with organic ligands [46], and coordination with histidine [3]. Another mechanism of detoxification is the formation of peptides [3,9,47-50]. We demonstrate below that LREEs are associated with peptides in leaves of D. dichotoma.

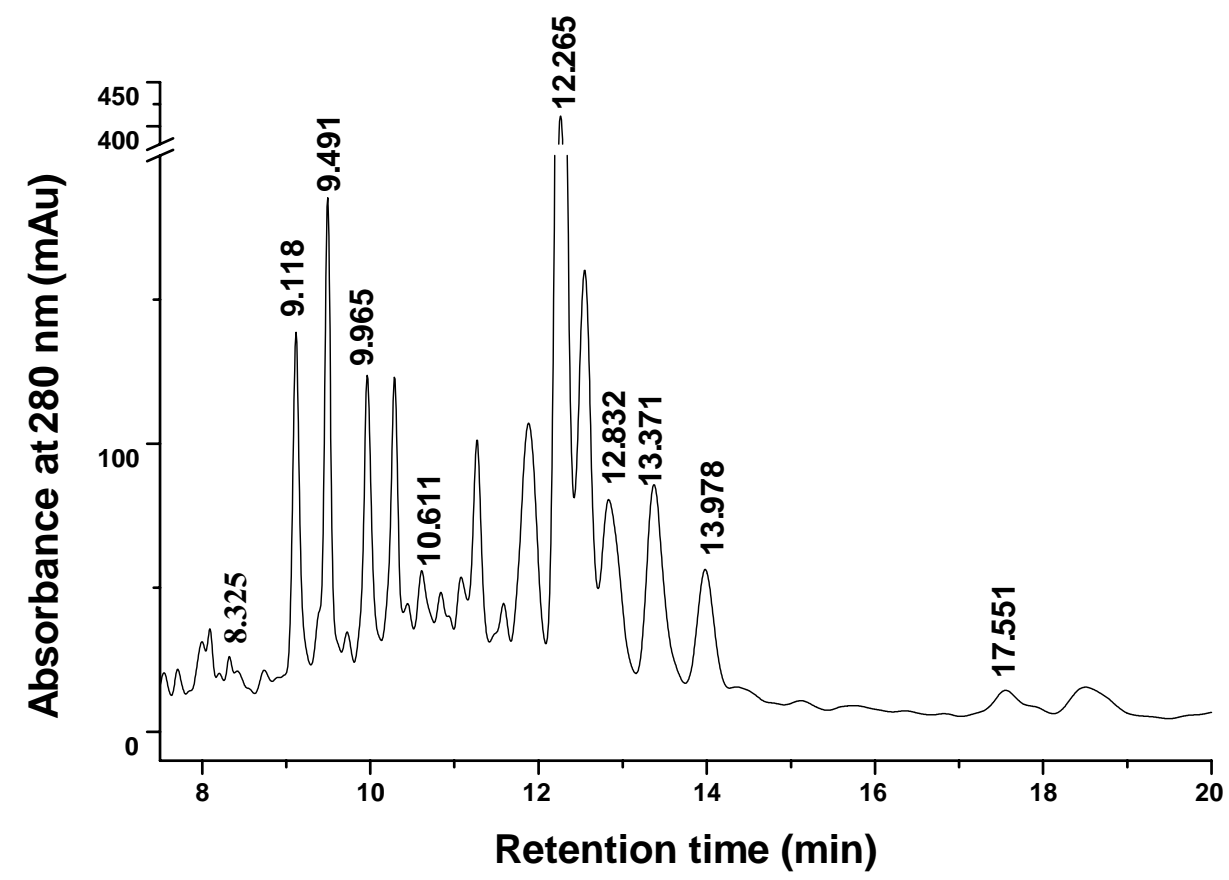

Fig. 5. HPLC chromatogram of purified peptides through Sephadex G-25. The peptides were applied to the RP-C 18 column and eluted with solvent A $\left(0.05 \% \mathrm{TFA}, \mathrm{v} / \mathrm{v}\right.$, in water) and $\mathrm{B}\left(0.05 \% \mathrm{TFA}, \mathrm{v} / \mathrm{v}\right.$, in acetonitrile) in gradient mode with flow-rate of $0.5 \mathrm{ml} \mathrm{min}^{-1}$. 

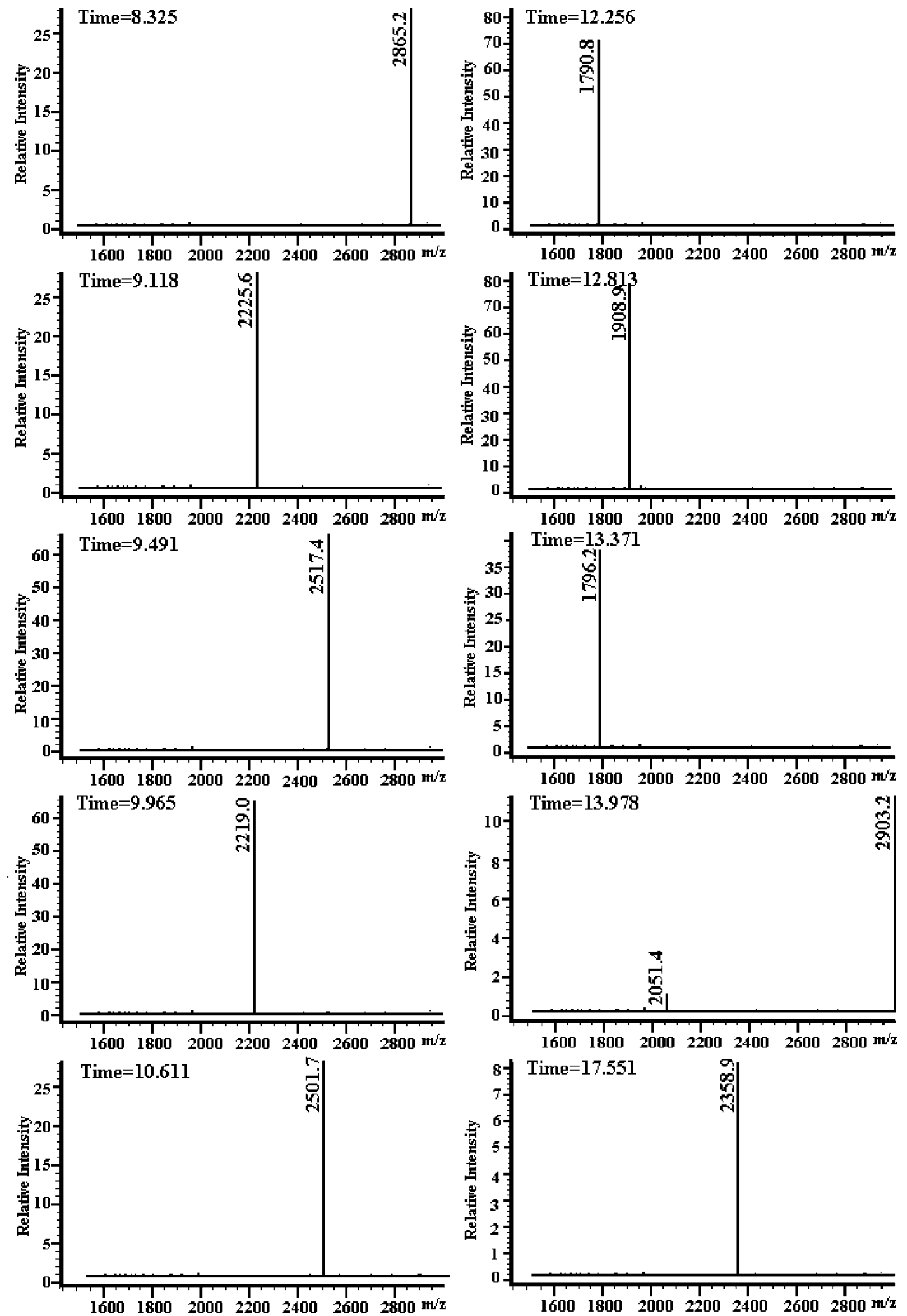

Fig. 6. Mass spectra of LREE-binding peptides with HPLC-ESI-MS. HPLC conditions were the same as that in Fig. 5.

Although this may not be sufficient to prove that formation of LREE binding peptides is engaged in the detoxification and homeostasis of LREEs, it does indicate that LREE-binding peptides contribute to rendering the metal ineffective.
The crudely purified peptides isolated from leaves (Fig. 1) were analyzed by reversed-phase ( $\mathrm{C}_{18}$ HPLC and ESI-MS), and the chromatograms and mass spectrum of peptides are shown in Figs. 5 and 6. Each eluted component (e.g. a 
specific peptide) as shown in Fig. 5 was collected, and the concentrations of LREEs (Table 5) in an individual component were determined by ICP-MS (see Section 2.7). Most peptides contained sub-ng $\mathrm{g}^{-1}$ to a maximum of $4.3 \mathrm{ng} \mathrm{g}^{-1}$ LREEs (Table 5). This suggests that the LREEs were bound to plant peptides although further purification and characterization of peptides were required. ESI-MS spectra (Fig. 6) indicated that the molecular weight of LREE-binding peptides was about 2000.

\section{Acknowledgements}

This study was supported by the National Natural Science Foundation of China (Grant No. 20237010 and 20177030). The Asian-Pacific Joint Environmental Laboratory of the Research Center for Eco-Environmental Sciences-Agilent Technologies was greatly appreciated for the mass analysis. The authors thank Dr. T.J. Tiberio for the improvement of written English.

\section{References}

[1] S.P. McGrath, C.M.D. Sidoli, A.J.M. Baker, R.D. Reeves, The potential for the use of metal-accumulating plants for the in situ decontamination of metal-polluted soils, in: H.J.P. Eijsackers, T. Hamers (Eds.), Integrated Soil and Sediment Research: A Basis for Proper Protection, Kluwer Academic Publishers, Dordrecht, 1993, pp. 673-676.

[2] A.J.M. Baker, R.D. Reeves, A.S.M. Hajar, Heavy metal accumulation and tolerance in British populations of the metallophyte Thlaspi caerulescens J. \& C. Presl (Brassicaceae), New J. Chem. 127 (1994) 61-68.

[3] U. Krämer, J.D. Cotter-Howells, J.M. Charnock, A.J.M. Baker, J.A.C. Smith, Free histidine as a metal chelator in plants that accumulate nickel, Nature 379 (1996) 635-638.

[4] U. Krämer, R.D. Smith, W. Wenzel, I. Raskin, D.E. Salt, The role of metal transport and tolerance in nickel hyperaccumulation by Thlaspi goesingense Halacsy, Plant Physiol. 115 (1997) 1641-1650.

[5] W. Rascio, Metal accumulation by some plants growing on $\mathrm{Zn}$ mine deposits, Oikos 29 (1977) 250-253.

[6] R.S. Boyd, N.S. Martens, Nickel hyperaccumulated by Thlaspi montanum var. montanum is acutely toxic to an insect herbivore, Oikos 70 (1994) 21-25.

[7] D.E. Salt, M. Blaylock, P.B.A.N. Kumar, V. Dushenkov, B.D. Ensley, I. Chet, I. Raskin, Phytoremediation: a novel strategy for the removal of toxic metals from the environment using plants, Biotechnology 13 (1995) 468-475.

[8] J.W. Huang, J. Chen, W.R. Berti, S.D. Cunningham, Phytoremediation of lead-contaminated soils: role of synthetic chelates in lead phytoextraction, Environ. Sci. Technol. 31 (1997) 800-805.

[9] W. Mathys, The role of malate, oxalate, and mustard oil glucosides in the evolution of zinc-resistance in herbage plants, Physiol. Plantarum 40 (1977) 130-136

[10] G. Nagahashi, W.W. Thomson, R.T. Leonard, The Casparian stripes a barrier to the movement of lanthanum in corn roots, Science 183 (1974) 670-671.

[11] A.C. Jorns, Presence and function of the Casparian band in roots of Norway Spruce [Picea abies (L.) karst.], J. Plant Physiol. 129 (1987) 493-496.

[12] U. Krämer, I.D. Pickering, R.C. Prince, I. Raskin, D.E. Salt, Subcellular localization and speciation of nickel in hyperaccumulator and non-accumulator Thlaspi species, Plant Physiol. 122 (2000) $1343-$ 1353.

[13] M.D. Vázquez, J. Barceló, C. Poschenrieder, J. Mádico, P. Hatton, A.J.M. Baker, G.H. Cope, Localization of zinc and cadmium in Thlaspi caerulescens (Brassicaceae), a metallophyte that can hyperaccumulate both metals, J. Plant Physiol. 140 (1992) 350-355.

[14] R.F.M. Van Steveninck, M.E. Van Steveninck, D.R. Fernando, W.J. Horst, H. Marschner, Deposition of zinc phytae in globular bodies in roots of (Deschampisa caespitosa) ecotypes a detoxification mechanism? J. Plant Physiol. 131 (1987) 247-257.

[15] H.M. Zimmermann, K. Hartmann, L. Schreiber, E. Steudle, Chemical composition of apoplastic transport barriers in relation to radial hydraulic conductivity of corn roots (Zea mays L.), Planta 210 (2000) 302-311.

[16] J.W. Oross, W.W. Thomson, The ultrastructure of Cynodon salt glands: the apoplast, Eur. J. Cell Biol. 28 (1982) 257-263.

[17] L.H. Wegner, K. Raschke, Ion channels in the xylem parenchyma of barley roots, Plant Physiol. 105 (1994) 799-813.

[18] M.D. Vázquez, C. Poschenrieder, I. Corrales, J. Barceló, Change in apoplastic aluminum during the initial growth response to aluminum by roots of a tolerant maize variety, Plant Physiol. 119 (1999) 435444.

[19] T.A. Peterson, E.S. Swanson, R.J. Hull, Use of lanthanum to trace apoplastic solute transport in intact plants, J. Exp. Bot. 37 (1986) 807-822.

[20] Y.Q. Wang, P. Jiang, F.Q. Guo, Z.Y. Zhang, J.X. Sun, REE bound DNA in natural plant, Sci. China Ser. B 42 (1999) 357-362.

[21] M. Mench, J.L. Morel, A. Gucker, B. Guillet, Metal binding with root exudates of low molecular weight, J. Soil Sci. 39 (1989) 521-527.

[22] X.E. Yang, V.C. Bligar, J.C. Foster, D.C. Martens, Accumulation and transport of nickel in relation to organic acids in ryegrass and maize grown with different nickel levels, Plant Soil 196 (1997) 271-276.

[23] G. Cieśliński, K.C.J.V. Rees, A.M. Szmigielska, G.S.R. Krishnamurti, P.M. Huang, Low-molecular-weight-organic acids in rhizosphere soils of durum wheat and their effect on cadmium bioaccumulation plant and soil, Plant Soil 203 (1998) 109-117.

[24] H.P. Leeuwen, Metal speciation dynamics and bioavailability: inert and labile complexes, Environ. Sci. Technol. 33 (1999) 3743-3748.

[25] Y.Q. Wang, J.X. Sun, H.M. Chen, F.Q. Guo, Determination of the contents and distribution characteristics of LREE in natural plants by NAA, J. Radioanal. Nucl. Chem. 219 (1997) 99-103.

[26] F.Q. Guo, Y.Q. Wang, J.X. Sun, H.M. Chen, Preliminary study on rare earth bound proteins in natural plant fern Dicranopteris dichotoma, J. Radioanal. Nucl. Chem. 209 (1996) 91-99.

[27] Y.Q. Wang, J.X. Sun, F.Q. Guo, Z.Y. Zhang, H.M. Chen, L. Xu, G.Y Cao, Study on binding of REEs with water-soluble polysaccharides in fern, Biol. Trace Elem. Res. 71/72 (1999) 103-108.

[28] F.S. Hong, Z.G. Wei, G.W. Zhao, Studies of bound form on rare earths in a natural plant fern Dicranopteris dichotoma by spectroscopy, Chem. J. Chin. Univ. 22 (2001) 1790-1794.

[29] H.Y. Yu, Y.S. Ding, S.F. Mou, P. Jandik, J. Cheng, Simultaneous determination of amino acids and carbohydrates by anion-exchange chromatography with integrated pulsed amperometric detection, J. Chromatogr. A 966 (2002) 89-97.

[30] S. Sugaya, A. Ohmiya, M. Kikuchi, T. Hayashi, Isolation and characterization of a $60 \mathrm{kDa}$ 24-D-binding protein from the shoot apices of peach trees (Prunus persica L.). It is a homologue of protein disulfide isomerase, Plant Cell Physiol. 41 (2000) 503-508.

[31] K.Y. Dunlop, L. Li, Automated mass analysis of low-molecular-mass bacterial proteome by liquid chromatography-electrospray ionization mass spectrometry, J. Chromatogr. A 925 (2001) 123-132.

[32] S.Z. Zhang, X.Q. Shan, L. Fuliang, Low molecular weight organic acids as extractant to predict plant bioavailability of rare earth elements, Int. J. Anal. Chem. 76 (2000) 283-294.

[33] D.A. Yuan, X.Q. Shan, Q. Hui, B. Wen, X.R. Zhou, Uptake and distribution of rare earth elements in rice seeds cultured in fertilizer solution of rare earth elements, Chemosphere 43 (2000) 327-337. 
[34] M.M. Lasat, A.J.M. Baker, L.V. Kochian, Physiological characterization of root $\mathrm{Zn}^{2+}$ absorption and translocation to shoots in $\mathrm{Zn}$ hyperaccumulator and nonaccumulator species of Thlaspi, Plant Physiol. 112 (1996) 1715-1722.

[35] C. Kelley, R.E. Mielke, D. Dimaquibo, Adsorption of Eu (III) onto roots of water hyacinth, Environ. Sci. Technol. 33 (1999) 14391443.

[36] G. Nagahashi, W.W. Thomson, R.T. Leonard, The Casparian strip as a barrier to the movement of lanthanum in corn roots, Science 183 (1974) 670-671;

R.F.M. Van Steveninck, M.E. Van Steveninck, A.J. Wells, D.R. Fernando, Zinc tolerance and the binding of zinc as zinc phytate in Lemna minor. X-ray microanalytical evidence, J. Plant Physiol. 137 (1990) $140-146$.

[37] E.P. Serieant, B. Dempsey, Ionisation Constants of Organic Acids in Aqueous Solutions, Pergamon Press, Oxford, 1979.

[38] D.D. Preein, Stability Constants of Metal-Ion Complexes. Part B. Organic Ligands, Pergamon Press, Oxford, 1979.

[39] D.E. Salt, R.C. Prince, A.J.M. Baker, I. Raskin, I.J. Pickering, Zinc ligands in the metal hyperaccumulator Thlaspi caerulescens as determined using X-ray absorption spectroscopy, Environ. Sci. Technol. 33 (1999) 712-717.

[40] X.Q. Shan, L. Jun, W. Bei, Effect of organic acids on adsorption and desorption of rare earth elements, Chemosphere 47 (2002) 701710 .

[41] Z.W. Wang, S.Z. Zhang, X.Q. Shan, Effects of low-molecularweight-organic-acids on uptake of lanthanum by wheat roots, Plant Soil, in press.
[42] R.P. Tolrà, C.H. Poschenrieder, J. Barciló, Zinc hyperaccumulation in Thlaspi caerulescens. II. Influence of organic acids, J. Plant Nutr. 19 (1996) 1541-1550.

[43] Z.G. Shen, F.J. Zhao, S.P. Mcgrath, Uptake and transport of zinc in the hyperaccumulator Thlaspi caerulescens and the nonhyperaccumulator Thlaspi ochroleucum, Plant Cell Environ. 20 (1997) 898-906.

[44] R.F.M. Van Steveninck, M.E. Van Steveninck, A.J. Wells, D.R. Fernando, Zinc tolerance and the binding of zinc as zinc phytate in Lemna minor. X-ray microanalytical evidence, J. Plant Physiol. 137 (1990) $140-146$.

[45] M.M. Lasat, A.J.M. Baker, L.V. Kochian, Altered Zn compartmentation in the root symplasm and stimulated $\mathrm{Zn}$ absorption into the leaf as mechanisms involved in Zn hyperaccumulation in Thlaspi caerulescens, Plant Physiol. 118 (1998) 875-883.

[46] J.L. Lee, D.R. Reeves, R.T. Brooks, T. Jaffer, Isolation and identification of a citrato-complex of nickel from nickel-accumulating plants, Phytochemistry 16 (1997) 1503-1505.

[47] J. Lee, R.D. Reeves, R.R. Brooks, T. Jaffré, The relation between nickel and citric acid in some nickel-accumulating plants, Phytochemistry 17 (1978) 1033-1035.

[48] G.J. Wagner, Characterization of a cadmium-binding complex of cabbage leaves, Plant Physiol. 76 (1984) 797-805.

[49] J.C. Steffens, The heavy metal-binding peptides of plants, Annu. Rev. Plant Physiol. 41 (1990) 553-575.

[50] C.S. Cobbett, P.B. Goldsbrough, Mechanisms of metal resistance: phytochelatins and metallothioneins, in: I. Raskin, B.D. Ensley (Eds.), Phytoremediation of Toxic Metals: Using Plants to Clean up the Environment, Wiley, New York, 1999, pp. 247-269. 